Saudi Journal of Humanities and Social Sciences

Abbreviated Key Title: Saudi J Humanities Soc Sci

ISSN 2415-6256 (Print) | ISSN 2415-6248 (Online)

Scholars Middle East Publishers, Dubai, United Arab Emirates

Journal homepage: https://saudijournals.com

Review Article

\title{
Mainstreaming the Culture of Peace into Nigerian Movies
}

\author{
Oyinloye Olaoluwa Babatunde A. PhD
}

Department of Peace and Conflict Studies, Afe Babalola University, Ado Ekiti, Nigeria

DOI: 1 10.36348/sjhss.2020.v05i11.006 $\quad$ |Received: 09.11.2020 | Accepted: 19.11 .2020 | Published: 30.11 .2020

*Corresponding author: Oyinloye Olaoluwa Babatunde A

\section{Abstract}

Film is an aspect of media as media is also an integral part of the agents of socialization. There are facts to show that films of which the brand name Nollywood is part of, being the second largest movie industry in the world in terms of film output, has strong ties with determining behavioral attitudes of its audience. This in relation with peace implies that Nollywood films could influence peace or violence attitudes. Earlier works have adopted theories from the field of peace studies in addressing the impact of Nollywood films but this work adopts theories from the field of peace studies and film studies it also used these theories in answering the research questions. Consequently this research therefore assessed the extent to which Nollywood promotes the culture of peace or the culture of violence, determining the key themes in Nollywood films and also its impact on its audience and the society at large. The research adopted Social Learning theory, Structural Functionalism theory and Cultivation theory for the investigation. The documentary research design is also adopted for this research. Primary and secondary data is gotten from the films selected and also through focus group discussion. The researcher through purposive sampling selects 5 films (Last Flight to Abuja, October 1, Dry, '76 and Alter Ego) that got nominated or won Best film of the year at the African Magic Viewer's Choice Award (AMVCA) from 2014-2018 with a sample size of 3,381 films. The focus group discussion had a target of 50 participants but got 34 participants, a semi structured interview guide was created and content analysis was used to analyze data. From the study, the following finds were reached. Nollywood films promote the culture of peace with a total of $11.6 \%$, Nollywood films also promote the culture of violence with a total of $25.2 \%$. The following themes were derived from the research Cultural promotion, patriotism, education, gender based violence, Structural Violence, Justice, Nudity, Tribalism and Romance, Crime. The research has being able to establish that Nollywood influences the behavioral pattern of its audience and also affects and influences the society being a part in a whole, it has ethical responsibilities. It can therefore be concluded that Nollywood promotes the culture of Violence while discouraging the culture of peace. From the research it is also determined that Nollywood have key themes in which the audience and viewers can derive when they watch the films. Nollywood is a part in a whole and not a standalone entity in the society. Nollywood also influences the behavioral patterns of its viewers. The researcher recommends that Peace scholars be co-opted into the Nigerian film and video censor board so as to contribute positively in identifying violent films so as to reduce its spread admits film lovers in Nigeria. The researcher also recommends that filmmakers should understand that they have ethical responsibilities to their audience and so contents in the films must be well crafted so as not to pass the wrong message.

Keywords: Culture of Peace, Peace, Culture of Violence, Violence, Nollywood, Films.

Copyright (C) 2020 The Author(s): This is an open-access article distributed under the terms of the Creative Commons Attribution 4.0 International License (CC BY-NC 4.0) which permits unrestricted use, distribution, and reproduction in any medium for non-commercial use provided the original author and source are credited.

\section{INTRODUCTION}

Entertainment and media industry is widely diversified and has witnessed transformation in terms of technology and applications in recent years. This transformation has led to global entertainment and media enterprises to offer innovative content and effective distribution models to stay ahead in the highly competitive market [1]. The media and entertainment industry consists of film, print, radio, and television. These segments include movies, music, newspapers, magazines, and books, radio shows, news, TV shows respectively. The shifting sands of technology and economics have created unique challenges across segments of the entertainment industry over the past quarter century [2]. Movie studios, musicians and performers are able to reach audiences over the Internet, which gives consumers more options for, and control over, entertainment [3].

$$
\text { Multinational entertainment/ media }
$$
conglomerates such as Vivendi, Sony, and AOL/Time Warner are increasingly becoming dominant in this 
sector, with operations that permit substantial economies across the line of entertainment products [4]. The process often begins with a literary work of fiction, which is then made into a movie exhibited in cinemas and later on syndicated and network television domestically and abroad, and finally released on home video [4]. The media is a significant force in modern culture. Sociologists refer to this as a mediated culture where media reflects the behavioral pattern of some individuals within a society [5]. The mass media has since been identified as one of the agents of socialization [6], others are family, religion, peer group and education. The media and entertainment industry is currently dominated by television (a platform where most audiences access movies), and is the most influential of all mass media (there is at least one in every home - said to watch an average of 7 hours a day) [6].

The entertainment industry has evolved over time to at a stage where it has birth concepts like "Edutainment". The term edutainment has been credited to Robert Heyman in 1973 conceptualized as the process of designing and executing a media message to educate and entertain in order to increase audience knowledge on an educational issue [7]. Edutainment can be defined as the act of learning through a medium that both educates and entertains using various digital media, such as animation, computer games, courseware, and mobile application or even still movies [7].

Movies or the movie industry is a media and has over the years helped in the consolidation and promotion of cultural heritage of different societies as agents of socialization, influencing popular culture. Since film is a subtle and powerful tool in passing information across to people and creating an image both domestically and internationally, government had often used it to communicate to their audience [8]. The best example is the United Arab Emirate (UAE), though it is monarchical Kingdom with a totalitarian system of government but it engaged movie producers in 1990 to project a positive image of the government to the world. They insisted that the films portray positive and good cultural values of the nation [9]. This submission is also supported by Okoye who quoted Prof. O. Enoch saying that "colonial administrators used movies to accelerate development in their various colonies" [10]. Movies have been in the world for years, history has it that the US film industry (popularly called Hollywood) is over 120 years old. It is the largest, oldest, and most profitable film industry in the world [11].

In 2017, the film industry in the United States generated approximately $\$ 10.24$ billion, making it the most profitable industry in the world. Major players in the US and Canadian film industry include MetroGoldwyn-Mayer, Paramount Pictures, 20th Century Fox, and AMC [11]. Hollywood film is the American ideological medium of mass communication; it has influenced the movie industry in several countries even African countries. Other film industries round the world include Bollywood (India), Cinema of China, Nollywood Kollywood (in Kenya), Jollywood (in Johannesburg), Ghollywood (in Ghana), Collywood (in Cameroon), or Bongowood (in Tanzania) [12], and a host of others. Nollywood is the second largest movie industry in the world in terms of film output, surpassing Hollywood in the U.S., and second only to Bollywood in India.

Nigeria's diverse cultural traditions and lifestyles offer a wealth of material from which the country's filmmakers skillfully draw to recount simple stories of daily life that resonate with Nigerians, as well as audiences sharing a similar culture and heritage across Africa and the African diaspora. These colorful and entertaining stories capture the imagination of audiences; they echo their life-experiences and feature a strong moral theme [13]. The prolific industry according to journalist Norimitsu Onishi, who helped coin the term "Nollywood" produces about 2,500 films a year [14].

The entertainment industry in Nigeria contributes N1.35 trillion to the country's GDP despite the fact that most businesses in the sector are built on personal business model with a growing number of private individuals beginning to form firm alliance [15]. At the Creative Nigerian Summit 2017, the then Minister of Finance, Mrs Kemi Adeosun acknowledged the potential of the Nigerian film industry. In her remark, she said that the industry is already captured at 1.42 per cent of the current GDP and that government is willing to provide all necessary support to help the industry achieve its full potential [16]. The role of the Nigerian entertainment industry has increasingly become important as it generates employment and serves as a tool for poverty alleviation. All segments of the entertainment industry in Nigeria are growing into multibillion-dollar businesses. The Nigerian Film \& Video Censors Board estimated that Nollywood employs about 1 million people in Nigeria and the board receives the production of about 2,500 movies annually.

From the foregoing, the legendary rise of Nollywood- Ayorinde affirms that "the idea of videofilm was introduced formally by Babatunde Adelusi (Adamson), a publisher of a defunct photo-play magazine. He believed that the movie would not only cut cost, but would imitate the Indians and Chinese, in terms of quality and quantity" [16]. As earlier established, movie industry, in this case, the Nigerian movie industry (Nollywood) itself is an agent of socialization which affects and influences the ideological frame of people and societies. In the years past, when humans were food gatherers, they evolved to become hunters who embraced the use of sharp instruments for hunting. Evolution came into play again 
and for reasons of satisfaction humans ventured into agriculture, food became surplus and they had to store food. Storage of food birth the motivation to steal, motivation to steal birth the motivation to defend gradually leading into groups coming together to plan for both negative and positive reason, more sophisticated weapons came up for both attack and defense. Today nations spend more on their security system and defense because of the enemy mentality, hence, the culture of Violence and war [18]. The culture of violence is embedded with an embrace of marginalization, inequality, injustice, segregation, and the likes.

The culture of violence based on distrust, suspicion, intolerance and hatred, on the inability to interact constructively with all those who are different, must be replaced by a new culture based on non-violence, tolerance, mutual understanding and solidarity, on the ability to solve peacefully disputes and conflicts. The world is in need of such a new culture and of a common system of values and new behavioral patterns for individuals, groups and nations, for, without them, the major problems of international and internal peace and security cannot be solved [19].

The Constitution of UNESCO begins, with a view to fulfilling the mission of the United Nations of avoiding "the scourge of war", as follows: "Since wars begin in the minds of men, it is in the minds of men that the defenses of peace must be constructed" [20], hence, the "Culture of Peace". According to the definition adopted by the United Nations General Assembly, a Culture of Peace consists "of values, attitudes and behaviors that reflect and inspire social interaction and sharing based on the principles of freedom, justice and democracy, all human rights, tolerance and solidarity, that reject violence and endeavor to prevent conflicts by tackling their root causes to solve problems through dialogue and negotiation and that guarantee the full exercise of all rights and the means to participate fully in the development process of their society" [21].

One of the ways in which the Culture of Peace gets injected into the stream of humanity is through education. Acknowledged by the United Nations, education is one of the tools for the advancement of the culture of peace. This was adopted together with some other tools like promoting sustainable economic and social development, fostering democratic participation etc., at the Culture of Peace and Non-Violence for the Children of the World (2001-2010), dedicated to Interreligious and intercultural dialogue and cooperation for peace [22]. Over the years, movies have been a tool for the dissemination of information and also communication [23]. In that light I would say film or movies as the case may be is an informal way of education as it is a tool with "...universal appeal and impact" [23]. Therefore it can be put thus that
Nollywood is an untapped resource for the promotion of the culture of peace and the undermining of the culture of violence.

The field of Peace research in itself, like other academic disciplines, has benefited from the interdisciplinary movements in fields that became ideologically divided over the last century. This movement in turn has presented several interesting opportunities from which to approach the art of Peace building and promotion from renewed perspectives [24]. Naturally, the power of filmmaking has been proven historically, used for connecting societies and dividing them, but the application of film to use as a tool in the framework of Peace building and promotion of culture of peace, presents a compelling challenge and opportunity. In an article by the United States Institute of Peace, it was poised that the broad field of peace building and the arts incorporates many modes of expression. It encompasses oral and written literary forms, vocal and instrumental musical works, drawing and painting, photography, movies, theater and dance, digital and broadcast arts [25]. In that light, Nollywood movies stand to be a force for the promotion of the Culture of Peace or the undermining of the culture of violence

The fact that Nollywood filmmakers make movies that are worthwhile and tell stories of African and Nigerian culture cannot be over emphasized. Just like the concept of dual use which mostly applies to technology and sciences, I will want to place Nollywood on the same scale. The concept of dual use is that a technology, say, has an intended use or primary purpose which is good (or at least not bad) and then gets used for a secondary purpose or use which is bad and is not intended by those who developed the technology in the first place [26]. This in relation to the materials (Films) produced by Nollywood in which the researcher or scientists are the Film makers and the technology produced are the films. This raises a call for ethical awareness for Film makers and producers as a film made with no bad intention can in turn be a tool that will teach bad vices and could influence negatively. Omorera Edemode and Aihevba in a research in Ekpoma (Nigeria) concludes that "There is a strong connection between the unwholesome and violent behaviors which the children regularly see on Nollywood videos and their physical exhibition of antisocial behaviors and attitudes such as the frequent use of swear and abusive words, indiscriminate use of lethal objects such as knives, guns, and membership of cult/gang groups, etc.," stating examples of films like "Issakaba, Beyond Sin, The Destroyer, Ukwa, Ultimate Warrior, Aki and Popo, Black Arrow, Cain and Abel 1\&2, Crazy Twins 1, Yahoo Boys etc" [27]. These films were not created with the intention to pass across or to educate ills but for entertainment but these films have been caught in the web of dual use. 
The Nigerian film industry addressed social conscience and contributes to world culture. It is my firm conviction that the film industry of any country should promote the wellbeing of humanity, which is an issue that is increasingly critical given the way in which movies play an ever-greater and more important role in society. Films in Nigeria are produced on comparatively low budgets but are extremely popular and have a huge influence and impact on popular opinion and culture [28].

Thousands of films have been produced by the Nigerian Film industry since its formation in the early $19^{\text {th }}$ century, making Nigeria a significant cultural exporter whose products dominate the African continent and African audiences around the world [29]. Nollywood films are "more than merely a form of entertainment..." [30]. It goes beyond a material that is only watched and stacked in cupboards or on internet pages [31], they are resources that affect the promotion of peace or violence in a society.

\section{Statement of the Problem}

There is no gain say that Nigerian Film Industry occupies a very important role in national development of the Nigerian Society and its cultures. Film is a means of communication with a universal appeal and impact [23]. The entertainment industry with focus on Nollywood is an agent of socialization and has ethical responsibilities to the society and to every single audience that consumes their products. Movies created or produced by them cannot stand neutral, as it would either have positive or negative effects on their audiences. Influencing ideological and behavioral expressions: therefore it is important to access the industry (Nollywood) to know the extent to which movies produced promote the culture of peace and or the culture of violence.

The overarching intention of this research is to determine the contribution of Nollywood to the promotion of culture of peace or the culture of violence in Nigeria. The scope of this research will be carved around award nominated films for overall best film from AMVCA (African Magic Viewer's Choice Awards) over the span of 5 years (2014-2018). Movies in this category usually represent the best of the industry having gone through rigorous screening methods before nomination or final selection as award winners. The Africa Magic Viewers' Choice Awards (AMVCA is an annual accolade presented by 'Multichoice'. MultiChoice is a South African company that operates the DStv Satellite Television service, a major satellite TV service in Sub-Saharan Africa. It is with this knowledge that the following movies are selected to help drive the course of this research as they have either won overall best film or have gotten nominated as an overall best film. Last Flight to Abuja (2014), October 1 (2015), Dry (2016), '76 (2017), Alter Ego (2018).

\section{Significance of the Study}

This research to Film makers and producers becomes significant as they will understand that they have ethical responsibilities to their audiences, knowing how to tell stories better through films that promotes the culture of peace rather than promote the culture of violence. Film will then become a tool for the indoctrination of peace values for future generation. Recently, the Nigerian Military signed an MOU with Film makers in Nigeria to enable Film makers tell the stories of past as it was [32]. It is also significant to the Nigerian Film and Censors Board as the organisation will be able to meticulously scrutinize every film so as to know which film is fit for audience consumption. It also paves way for inter disciplinary studies, such as this, which is in the spectrum of film studies, peace studies, conflict resolution and international studies. This study portrays an understanding of the approach to the study of film studies. Lastly, it opens new platforms for further research in film and peace studies as it relates to nation building and sustainable peace.

The research employed documentary research design as this will be used to supply answers to the research questions. The sampling method employed is purposive sampling technique. And population size is the total number of films approved by the National Film and Video Censor Board for home entertainment and exhibition between the year 2014 and 2018. This totals 3,381 films. The types of data to be used for the analysis of this research are drawn from both primary and secondary sources. The primary source is gotten through focus group discussion and observation. The researcher gathered 50 people (from different works of life and age group as Nollywood movies have by both young and old as audiences). The secondary sources are nominated films for overall best film from AMVCA (African Magic Viewer's Choice Awards) over the span of 5 years (2014-2018). They are Last Flight to Abuja (2014), October 1 (2015), Dry (2016), '76 (2017), Alter Ego (2018). The researcher uses the content analysis method, drawing out the elements that promote the culture of peace and also elements that promote the culture of violence in the selected movies. The researcher focused on aspects of dialogues and actions to arrive at a conclusion.

\section{FINDINGS}

In line with the research objectives and after the research process, the following are the key findings:

a. It can be deduced that Nollywood films promote $11.6 \%$ of culture of peace. Inculcating the attributes of the culture of peace into the society can be done through peace education and Nollywood films have been able to educate on the culture of peace. 
b. It must be stated that from the selected films, Nollywood films promote $25.2 \%$ of the culture of violence. Form the knowledge gotten from the first and second objective of this research work, it can therefore be concluded that Nollywood promotes the culture of Violence $(25.2 \%)$ while undermining the culture of peace $(11.6 \%)$. From the foregoing, it should also be noted that Nollywood films project the themes of violence in order to project or educate the masses on the culture of peace.

c. Deduction of the thematic underpinnings of Nollywood films. The films selected which are products of Nollywood have been watched and researched with the aid of content analysis and the following themes have been deduced. They are: Cultural promotion, patriotism, education, gender based violence, Structural Violence, Justice, Nudity, Tribalism and Romance, Crime.

\section{CONCLUSION}

The fact remains that Nollywood films has eaten deep into the stream of the society as citizens of Nigeria get to watch Nollywood films from different platforms (DSTV- African Magic, Youtube, Netflix etc) and this in-turn affects their behavioral patterns directly or indirectly. Nollywood being an agent of socialization is a part in a whole, in the sense that it occupies a part in the society and the space being occupied is that which affects behaviors of audiences which in-turn affect the flow of the society. Nollywood films and film makers have ethical responsibilities to their audience and so films should be made with this understanding. From this study it is can be concluded that Nollywood promotes the culture of violence while undermining the culture of peace. Hence it is highly suggested that deliberate efforts be made to mainstream the culture of peace into the productions of Nollywood movies. This will help in no small way towards fulfilling the sustainable millennium development goal 16 by promoting the societal fabric of peace through the reduction of the violence advocating components in Nollywood movies.

\section{REFERENCES}

1. Market Watch. (2019, August 23). MarketWatch. Retrieved Jan 20, 2020, from Entertainment and Media Market Share,Size 2019 Industry Development Analysis, Global Trends , Growth Factors, CAGR Status, Industry Insights by Top Key Players and, Forecast to 2023: https://www.marketwatch.com/pressrelease/entertainment-and-media-marketsharesize-2019-industry-development-analysisglobal-trends-growth-factors-cagr-status-industryinsights-by-top-key-players-and-forecast-to-20232019-08-23.

2. SingularDTV. (2018, August 9). Singular DTV. Retrieved Jan 22, 2020, from https://medium.com/singulardtv/30-stats-thatreveal-the-economics-of-the-entertainmentindustry-18e9a5db493b

3. DeBenedetti, J. (2018). Analysis of the Entertainment Industry. Retrieved jan 22, 2020, from

Chron:

https://smallbusiness.chron.com/analysisentertainment-industry-78237.html

4. Encyclopedia. (2019, dec 23). Entertainment Industry. Retrieved jan 23, 2020, from Encyclopedia:

https://www.encyclopedia.com/social-sciencesand-law/economics-business-and-

labor/businesses-and-occupations/entertainmentindustry

5. Bartleby. (2011, dec 7). Mass Media as an Agent of Socialisation. Retrieved jan 22, 2020, from bartleby: https://www.bartleby.com/essay/MassMedia-as-an-Agent-of-SocialisationF3ZSQC29K6ZYA

6. Polytechpanthers. (2012). Socializing the individual. Retrieved from pdf: https://www.polytechpanthers.com/ourpages/auto/ 2012/1/24/38921225/Ch5S3\%20$\% 20$ Agents $\% 20$ of\%20Socialization.pdf

7. Binti, N. (2014). Edutainment. Retrieved jan 4, 2020, from New Academic Learning Innovation : http://ctl.utm.my/nali/projek-projek-dawahnali/student-to-student-edutainment/

8. Maton, Y. A. (2018). The Nigerian Entertainment Industry (Nollywood) Culture and Society Being . Sociology and Anthropology http://www.hrpub.org.

9. Yunis, A. (2016, may 20). Film as nation building: the UAE goes into movie business. CINEJ cinema Journal Vol. 3 no. 2. Retrieved jan 20, 2020, from https://cinej.pitt.edu/ojs/index.php/cinej/article/vie w/98/27 1

10. Okoye, K. (2014). Retrieved Jan 20, 2020, from Nigeria's film industry and nation building. Nigeria: : www.peoplesdailyng.com/nigerias-filmindustry-and-natio n-building/

11. Tufilamu Pictures. (2018, May 31). TOP FIVE LARGEST FILM INDUSTRIES IN THE WORLD. Retrieved Jan 21, 2020, from http://www.tufilamupictures.com/top-five-largestfilm-industries-world/

12. Endong, F. P. (2017). Nollywood in Cameroon: Transnationalisation and Reception of a Dynamic Cinematic Culture. Cinej Cinema Journal Vol 6.

13. Oyewole, O. A., Inselsbacher, E., \& Näsholm, T. (2014). Direct estimation of mass flow and diffusion of nitrogen compounds in solution and soil. New Phytologist, 201(3), 1056-1064.

14. Polanco, L. (2018, 09 01). A New Nollywood: A Close Second To Bollywood, Larger Than Hollywood. Retrieved Jan 21, 2020, from Videoage:

https://www.videoageinternational.net/2018/01/09/ 
cover-stories/a-new-nollywood-a-close-second-tobollywood-larger-than-hollywood/

15. Nigerian Entertainment Conference. (2017). Key Summary Of the Nigerian Entertainment Industry. Retrieved 11 20, 2019, from https://nec.ng/wpcontent/uploads/2017/03/NIGERIANENTERTAINMENT-INDUSTRY.pdf

16. Creative Nigeria Summit. (2017). Retrieved 11 23, 2019, from Financing the FIlm, Television and Music Industries. www.channelstv.com/2017/07/17/fg-promises-taxrelief

17. Ayorinde, S. (1996, June 6). Rave of the Video. In The Guardian. p. 29.

18. Akinyoade Demola. (2019). Conflict Resolution. Lecture.

19. Symonides, J., \& Singh, K. (1996). Constructing a culture of peace:challenges and perspectives anintroductory note. In UNESCO, From a Culture of Violence to a culture of PEace. United Nations Educational,Scientific and Cultural Organization, 7 place de Fontenoy, 75352 Paris 07 SP, FranceComposed by Éditions du Mouflon, 94270 Le Kremlin-Bicêtre, FrancePrinted by Presses Universitaires de France, Vendôme.

20. Mayor, F. (1987-99). CULTURE OF PEACE. INSTITUTIONAL ISSUES INVOLVING ETHICS AND JUSTICE, pdf.

21. United Nations. (1992). Retrieved 11 5, 2019, from The United Nations: http://cpnnworld.org/learn/un.html

22. Mayor, M., Marmier, M., Lovis, C., Udry, S., Ségransan, D., Pepe, F., ... \& Curto, G. L. (2011). The HARPS search for southern extra-solar planets XXXIV. Occurrence, mass distribution and orbital properties of super-Earths and Neptunemass planets. arXiv preprint arXiv:1109.2497.
23. Adenugba, O. (2008). Retrieved 11 22, 2019, from The role of film in national development: filminnaija.blogspot.com.ng/2008/06/role-of-filmin-national-development.html

24. Curtis, M. (2016). Film as a Tool for Conflict Transformation. Castellon, Spain.

25. Cohen, C. E. (2015). Arts and Building Peace: Affirming the Basics and Envisioning the Future. Retrieved $11 \quad 3, \quad 2019$, from https://www.usip.org/sites/default/files/Insights_S ummer-2015-Arts-Peacebuilding.pdf

26. Resnik, D. (2009). "What is Dual Use Research? A Response to Miller and Selgelid",. Science and Engineering Ethics, 15: 3-5.

27. Omoera, O., Edemode, O., \& Aihevba, P. (2017). Impact Of Nollywood Films On Children's Behaviour In Ekpoma, Nigeria. Asian and African Studies, Volume 26, Number 2,

28. Onuzulike, U. (2008). Nollywood: The Birth of Nollywood: the Nigerian Movie industry . Black Camera, 26.

29. Schnell, B. (2017). Stop Comparing Nollywood to Hollywood: Reorienting Western Understanding of. Retrieved 10 21, 2019, from pdf

30. Nykon, B. P. (2011). The Feature Film as a Vehicle for Disseminating Principles of Conflict Resolution. Jornal of Conflictology, 19.

31. Das, A. (2009). Political Crisis and Media's Role towards Conflict Resolution: A Study in Indian Context. Retrieved 10 20, 2019, from http://utcc2.utcc.ac.th/localuser/amsar/PDF/Docu ment52/Arjun_Template.pdf

32. Agency, N. (2019, 11 1). Filmmakers partner with DHQ for military movies. Retrieved 11 5, 2019, from the cable lifestyle: https://lifestyle.thecable.ng/filmmakers-dhqpartner-to-correct-wrong-narratives-about-themilitary/ 